\title{
TINGGALAN ARKEOLOGI MASA KOLONIAL DI WILAYAH KEPULAUAN MALUKU: Sebuah Evaluasi Hasil Penelitian ${ }^{1}$
}

\author{
Archaeological Remains of Colonial Period In The Maluku Islands: \\ Research Review
}

\author{
Syahruddin Mansyur \\ BALAI ARKEOLOGI AMBON \\ hitam_putih07@yahoo.com
}

\begin{abstract}
Abstrak
Balai Arkeologi Ambon dengan wilayah kerja meliputi Provinsi Maluku dan Maluku Utara (selanjutnya disebut wilayah Kepulauan Maluku) telah menetapkan tema penelitian yang sesuai dengan kondisi wilayah kerjanya. Salah satu tema yang dikembangkan dalam pelaksanaan penelitian arkeologi di Balai Arkeologi Ambon adalah tema Pengaruh Kolonial di Nusantara. Hal ini, tentu saja tidak lepas dari sejarah kebudayaan yang pernah ada dan berkembang di wilayah Kepuluan Maluku. Seperti diketahui bahwa sejarah kedatangan bangsa asing terutama bangsa Eropa di nusantara diawali oleh faktor ekonomi yaitu perdagangan rempah-rempah, dimana wilayah Kepulauan Maluku merupakan pusat produksi dua jenis rempah-rempah yaitu cengkeh dan pala. Dalam konteks inilah, penelitian arkeologi yang dilaksanakan oleh Balai Arkeologi Ambon melalui tema Pengaruh Kolonial berupaya untuk mengkaji lebih jauh berbagai aspek yang terkait dengan masa penguasaan bangsa Eropa di wilayah Kepulauan Maluku. Makalah ini akan merangkum berbagai hasil penelitian arkeologi yang dilakukan oleh Balai Arkeologi Ambon sejak didirikan pada tahun 1995 hingga saat ini. Selanjutnya, akan dipaparkan ruang lingkup penjelasan yang tercakup dalam berbagai hasil penelitian yang telah dilaksanakan. Makalah ini juga berupaya melakukan evaluasi terhadap berbagai aspek terkait dengan tema pengaruh kolonial khususnya di wilayah Kepulauan Maluku.
\end{abstract}

Kata Kunci: Tinggalan Arkeologi, Kolonial, Penelitian, Evaluasi

\begin{abstract}
Archaeological Institute of Ambon with work areas include Maluku and North Maluku (hereinafter referred to as the Moluccas Islands) has set the theme of the research in accordance with the conditions of their working area. One of the themes developed in the implementation of archaeological research at the Institute of Archaeology of Colonial Influence Ambon is a theme in the archipelago. It is, of course, can not be separated from the cultural history that ever existed and flourished in the area of Moluccas Islands. As it is known that the history of the arrival of foreigners, especially Europeans in the archipelago preceded by economic factors, namely the spice trade, which is the center of the Maluku Islands of production of two types of spices are cloves and nutmeg. In this context, archaeological research carried out by the Archaeological Institute of Ambon through the Colonial Influence theme seeks to further examine various aspects linked to the control of European nations in the Moluccas Islands. This paper will summarize the results of archaeological research carried out by the Archaeological Institute of Ambon since its inception in 1995 until today. Furthermore, an explanation will be presented scope covered by the various studies that have been conducted. This paper also attempts to evaluate the various aspects related to the theme of colonial influence, especially in the Maluku Islands.
\end{abstract}

Keywords: Archaeological remains, Colonial, Research, Evaluation

1 Naskah awal tulisan ini pernah disampaikan dalam Evaluasi Hasil Penelitian Arkeologi (EHPA) yang diselenggarakan oleh Balai Arkeologi Ambon pada Januari 2012 di Ambon. 


\section{PENDAHULUAN}

Dalam lingkup nasional, kebijakan penelitian arkeologi di Indonesia telah dirumuskan oleh Pusat Penelitian dan Pengembangan Arkeologi Nasional atau disingkat PUSLITBANG ARKENAS. Dalam rumusan kebijakan tersebut, telah ditetapkan 9 tema penelitian yang lebih dititikberatkan pada kronologi sejarah kebudayaan di nusantara yaitu: Manusia purba, budaya dan lingkungannya; Manusia dan budaya akhir masa plestosen; Manusia dan budaya berpenutur Austronesia; Peradaban awa sejarah di Nusantara; Peradaban Hindu-Budh di Nusantara; Peradaban Pengaruh Islan di Nusantara; Peradaban pengaruh Kolonia di Nusantara; CRM (Curtural Resources Management) atau Manajemen Sumberdaya Budaya; dan Arkeologi Maritim. Tentu saja, kesembilan tema tersebut akan disesuaikan dengan kondisi yang ada di wilayah penelitian masing-masing balai arkeologi yang tersebar di seluruh Indonesia.

Selanjutnya, Balai Arkeologi Ambon dengan wilayah kerja meliputi Provins Maluku dan Maluku Utara (selanjutnya disebut wilayah Kepulauan Maluku) telah menetapkan pula tema penelitian yang sesuai dengan kondisi wilayah kerjanya Salah satu tema yang dikembangkan dalam pelaksanaan penelitian arkeologi di Bala Arkeologi Ambon adalah tema ketujuh yaitu tema Pengaruh Kolonial di Nusantara. Hal ini, tentu saja tidak lepas dari sejarah kebudayaan yang pernah ada dan berkembang di wilayah Kepuluan Maluku. Seperti diketahui bahwa sejarah kedatangan bangsa asing terutama bangsa Eropa di nusantara diawali oleh faktor ekonomi yaitu perdagangan rempahrempah, dimana wilayah Kepulauan Maluku merupakan pusat produksi dua jenis rempahrempah yaitu cengkeh dan pala.

Pada awalnya, perdagangan rempahrempah di nusantara (termasuk jenis cengkeh dan pala) berada di tangan pedagangpedagang Nusantara, Cina dan Arab. Namun, seiring dengan kebutuhan dan keuntungan yang dihasilkan dari perdagangan ini, maka bangsa Eropa kemudian tertarik untuk memperoleh jenis komoditi ini langsung dari pusat produksinya. Demikian, dalam perkembangan selanjutnya bangsa Eropa menguasai perdagangan rempah-rempah di Kepulauan Maluku khusunya Belanda (melalui serikat dagangnya yaitu VOC) yang berhasil menerapkan kebijakan monopoli cengkeh dan pala. Kebijakan tersebut, kemudian mempengaruhi berbagai aspek kehidupan, diantaranya aspek politik, ekonomi, sosial, dan budaya.

Dalam konteks inilah, penelitian arkeologi yang dilaksanakan oleh Balai Arkeologi Ambon melalui tema Pengaruh Kolonial berupaya mengkaji lebih jauh berbagai aspek yang terkait dengan masa penguasaan bangsa Eropa di wilayah Kepulauan Maluku. Keseluruhan proses tersebut memberi andil atau berpengaruh terhadap bentuk keragaman budaya baru dapat diamati langsung sebagai peninggalan arkeologi (Harkatiningsih, 2009).

Makalah ini akan merangkum berbaga hasil penelitian arkeologi yang dilakukan oleh Balai Arkeologi Ambon sejak didirikan pada tahun 1995 hingga saat ini. Selain itu, makalah ini juga akan merangkum berbagai tulisan yang terkait dengan topik pengaruh kolonial di wilayah Maluku. Selanjutnya, akan dipaparkan ruang lingkup penjelasan yang tercakup dalam berbagai hasil penelitian yang telah dilaksanakan. Makalah ini juga berupaya melakukan evaluasi terhadap berbagai aspek terkait dengan tema pengaruh kolonial khususnya di wilayah Kepulauan Maluku.

REKAM JEJAK HASIL PENELITIAN: Tema Pengaruh Kolonial Di Wilayah Kepulauan Maluku

Balai Arkeologi Ambon dibentuk pada tahun 1995, dan hingga tahun 2011 telah melakukan berbagai penelitian yang dapat dikelompokkan dalam lingkup tema pengaruh kolonial di wilayah Kepulauan Maluku. Selain penelitian yang dilakukan oleh Balai Arkeologi Ambon, penelitian lain yang dapat memberi gambaran tentang pengaruh kolonial di wilayah Kepulauan Maluku, juga dilakukan oleh Pusat Penelitian dan Pengembangan Arkeologi Nasional. Penelitian-penelitian tersebut bertujuan untuk melakukan identifikasi peninggalan arkeologi masa kolonial di Maluku. Penelitianpenelitian dilaksanakan di daerah-daerah yang dianggap mampu memberikan informasi tentang proses kekuasaan kolonial yang pernah terjadi di masa lampau, sehingga tampak jelas peran penting suatu wilayah dalam pengaruh kolonial. Lokasi-lokasi yang telah diteliti tersebut, diantaranya; Di Pulau Haruku dilakukan penelitian yang mengidentifikasi tinggalan arkeologi yaitu Benteng Horn, Benteng Rohomoni, Benteng Nieuw Zeelandia. Di Pulau Wokam (Maluku Tenggara) dilakukan penelitian yang mengidentifikasi tinggalan arkeologi berupa sisa struktur benteng. Di Pulau Kisar (Maluku Barat Daya) dilakukan penelitian yang mengidentifikasi tinggalan arkeologi yaitu benteng Vollen Haven dan Benteng Delles Haven serta gereja tua. Di Lako Akelamo (Halmahera Barat/Maluku Utara) dilakukan penelitian yang mengidentifikasi struktur bangunan berupa benteng yang oleh masyarakat setempat disebut Benteng Say Loko. Di Pulau Bacan (Maluku Utara) dilakukan penelitian yang mengidentifikasi tinggalan arkeologi yaitu Benteng Barneveld, meriam, kompleks makam Eropa, bekas pabrik kopi, serta bangunan perkantoran dan rumah tinggal. Peninggalan lain yang ada di kota Bacan berupa bangunan adalah bekas gedung kantor wakil pemerintah Belanda yang ditempatkan di Kesultanan Bacan. Sementara itu, di Kampung Makian yang terletak sekitar $\pm 10 \mathrm{~km}$ ke arah timur laut dari pusat kota Bacan, terdapat sisa struktur bangunan yang dulunya merupakan rumah tinggal pengelola perkebunan dan pabrik kopi.

Lokasi lain adalah Pulau Saparua, yang mengidentifikasi tinggalan arkeologi yang ada di Kota Saparua yaitu benteng Duurstede,
Bangunan Pemerintahan (Kantor Residen, Rumah Dinas Residen, Kantor Pengadilan, Lembaga Pemasyarakatan, Kantor Pos, Kantor Polisi), Rumah Sakit Kusta, Sekolah (HIS, Sekolah Melayu, dan Sekolah Cina) Rumah Tinggal, Pasar, dan dermaga. Selain itu, diidentifikasi juga beberapa toponim yaitu Kerkof, Bong (Kuburan Cina), Kampung Cina, dan Kampung Arab. Di Pulau Buru dilakukan penelitian yang berhasil mengidentifikasi tinggalan arkeologi yang berkaitan dengan masa penguasaan Belanda yaitu: Benteng Defensie (Kayeli), Kantor Pemerintahan, dan Rumah Tinggal Pejabat Pemerintahan. Selain itu, diidentifikasi tinggalan arkeologi yang berkaitan dengan masa Perang Dunia II, yaitu Stelling (pillbox), lapangan terbang, dan lokasi pendaratan tentara Australia. Penelitian yang dilakukan di Morotai (Maluku Utara) berhasil mengidentifikasi tinggalan arkeologi yang merupakan sisa Perang Dunia II, diantaranya kendaraan tempur, berbagai jenis senjata, berbagai jenis proyektil, berbagai jenis peralatan makan, dan berbagai jenis peralatan listrik. Selain itu, diidentifikasi juga beberapa toponim yaitu lokasi pendaratan sekutu, Army Dock, lapangan terbang, dan sisa-sisa struktur yang merupakan lokasi barak-barak tentara sekutu.

Selain penelitian yang dilakukan oleh Balai Arkeologi Ambon dan Pusa Penelitian dan Pengembangan Arkeolog Nasional, penelitian lain juga dilakukan oleh Pusat Dokumentasi Arsitektur (PDA). Penelitian oleh PDA adalah inventarisasi atas sarana pertahanan (baik benteng Portugis, Spanyol, Belanda, dan Inggris maupun saran pertahanan masa Perang Dunia II) yang ada di Kepulauan Maluku. Hasil inventarisasi PDA terhadap titik lokasi sarana pertahanan di wilayah Provinsi Maluku adalah sebanyak 83 benteng dan Provinsi Maluku Utara sebanyak 38 benteng (Effendi dan Mansyur: 2007)

\section{RUANG LINGKUP BAHASAN HASIL} PENELITIAN

Berdasarkan hasil penelitian yan dilakukan di beberapa daerah di wilayah 
Kepulauan Maluku telah memberikan informasi tentang berbagai aspek dalam kaitannya dengan pengaruh kolonial. Aspek-aspek tersebut, diantaranya sistem pertahanan kolonial untuk mendukung kebijakan monopoli cengkeh dan pala, tata niaga cengkeh dan pala, serta perkembangan struktur kota di daerah-daerah yang dianggap penting.

\section{Sistem Pertahanan Kolonia}

Dengan menerapkan strategi dan sistem pertahanan pada awal pendudukannya di setiap daerah yang mereka anggap penting atau menguntungkan maka penguasaan tersebut dapat berlangsung selama berabadabad. Abbas (2005), menyebutkan bahwa faktor-faktor yang melatari pemilihan lokas pendirian sebuah benteng diantaranya:

1. Pentingnya suatu daerah pada masa pendirian benteng (misalnya potensi tempat itu untuk dijadikan pusat perdagangan, adanya suplai produks yang dibutuhkan, dan potensi untuk digunakan sebagai pusat pemerintahan lokal)

2. Ancaman atau penolakan yang dihadapi (misalnya ancaman eksternal dari orang-orang asing atau ancaman internal dari penguasa setempat).

3. Strategi yang diterapkan dalam upayanya menaklukkan suatu wilayah tertentu untuk perluasan kekuasaan.

Khusus untuk wilayah Maluku, daerah-daerah yang dianggap penting pada saat itu diantaranya, Kepulauan Banda, Kepulauan Ambon (dan pulau-pulau Lease) serta Maluku Utara (Moluco Kie Raha). Daerah-daerah ini dianggap penting karena merupakan daerah pengumpul dalam perdagangan rempah-rempah sebelum dibawa ke pedagang-pedagang Internasiona di Malaka atau langsung ke Eropa (Mansyur, 2006).

Berdasarkan pengamatan terhadap keletakan benteng yang ada di Maluku yait benteng yang ditempatkan di daerah pesisir dan daerah perbukitan memberikan asumsi bahwa benteng yang dibangun di daerah pesisir berkaitan dengan strategi dan taktik perang maritim. Profil wilayah Maluku yang merupakan wilayah Kepulauan sangat tepat merupakan wilayah Kepulauan sangat tepat
dengan strategi ini. Benteng-benteng yang dibangun sebelum abad XVII oleh Portugis dan Inggris, diambil alih oleh Belanda untuk memperkuat sistem pertahanan mereka di Maluku. Ternate, Bacan, Jailolo (Halmahera) dan Kepulauan Banda merupakan daerah yang diperkuat oleh Portugis dengan bentengbenteng pertahanan, akan tetapi dengan berbagai pertimbangan dan perubahan politik di Eropa maka benteng-benteng tersebut ditinggalkan. Hal ini, menjadi keuntungan tersendiri bagi Belanda dan tidak perlu mengeluarkan biaya untuk memperkuat daerah-daerah penting di Kepulauan Maluku (Ibid).

Secara kronologis sistem pertahanan pada abad XVI didominasi oleh Portugis dengan membangun 3 benteng pertahanan diantaranya pada tahun 1512,1532 dan 1640 di Ternate. Sistem pertahanan yang kuat dibangun oleh Portugis sebagai langkah antisipasi terhadap serangan pesaingnya sesama bangsa Eropa di Ternate. Sementara itu, persaingan antara Ternate yang didukung oleh Portugis dan Tidore yang didukung oleh Spayol memberi andil cukup besar dalam sistem pertahanan yang dibangun di wilayah ini. Di pihak lain, Belanda yang memperkuat pertahanannya di bagian selatan terutama Ambon dan Banda berebut pengaruh dengan Inggris. Akan tetapi, beberapa perubahan politik antara Belanda dan Inggris menyebabkan kedua negara ini mengadakan perjanjian rahasia untuk memaksa Portugis dan Spayol hengkang dari wilayah ini. Perjanjian pada tanggal 17 Juli 1619 itu berisi tentang pembagian pembiayaan untuk "proyek" tersebut, East India Company (Inggris) menyediakan sepertiga dari tenaga manusia, biaya dan kapal sedangkan Vereenigde Oost Indische (Belanda) menyediakan dua pertiga sisanya (Hanna, 1983:49; dalam ibid).

Pada abad XVII, sistem pertahanan didominasi oleh Belanda dengan memperkuat daerah-daerah yaitu pulau Ambon sebagai pusat aktifitas perdagangan dan pemerintahan. Sebagian besar dari benteng tersebut ditempatkan di Hitu untuk meredam perlawanan rakyat Hitu. Dan di Saparua diantaranya, benteng Duurstede pada tahun 1690/1691, Hollandia pada tahun 1690, dan Fort Delf dan Ouw. Salah satu benteng tersebut menjadi kubu pertahanan dalam perang besar Belanda meredam perlawanan rakyat Maluku dibawah kepemimpinan Kapitan Pattimura. Demikian pula dengan pulau di sekitarnya yaitu pulau Haruku.. Daerah lain yang tidak kalah strategisnya, dimana pulau ini dianggap sangat penting mengingat daerah ini sebagai penghasil pala terbesar di Maluku. Selain itu, benteng-benteng yang dibangun di pulau-pulau lain dimaksudkan sebagai pos pengawas bagi perkebunan-perkebunan Belanda. Diantaranya, benteng Hardewyk pada tahun 1628-1631 dan Fort Wantrow pada tahun 1657 di Seram dan benteng Fort Dellen Haven pada tahun 1665 di pulau Kisar (Ibid). Sejarah penguasaan VOC dan pemerintah Belanda atas berbagai wilayah di Maluku dibagi dalam tiga fase yaitu:

1. Pada awal kedatangannya VOC pada saat itu hanya menempatkan wakilwakil perdagangannya diberbagai wilayah di Maluku. Hal ini karena pada awalnya mereka datang dengan tujuan perdagangan.

2. Fase selanjutnya dengan tujuan memonopoli perdagangan rempahrempah dan berbagai komoditi lainnya. Mereka kemudian membangun bentengbenteng pertahanan untuk meredam perlawanan penguasa-penguasa lokal dan memenangkan persaingan dengan pedagang-pedagang asing lainnya. Pada masa ini, mereka mengatur berbagai urusan perdagangan dan hal-hal lainnya di dalam benteng (kehidupan intra muros)

3. Dan fase terakhir berlangsung setelah keadaan mulai kondusif dan perlawananperlawanan rakyat Maluku berhasil diredam. Fase ini juga ditandai dengan pembangunan berbagai fasilitas di luar benteng oleh Pemerintah Belanda, dengan adanya berbagai fasilitas ini maka kehidupan kota kolonial telah dimulai. Kota-kota yang ada di Maluku sepert Ambon, Banda, Ternate, dan Tidore bahkan kota-kota kecil memperlihatkan hal ini. Tidak hanya itu, perusahaanperusahaan swasta bahkan diberikan hak oleh Pemerintah Belanda untuk mengelola perkebunan-perkebunannya. Faktor lain yang menyebabkan keleluasaan Pemerintah Belanda di nusantara pada umumnya adalah adanya perjanjian antara Negara-negara kolonial di Eropa yang menyepakati penguasaan atas wilayah-wilayah jajahan mereka (Ibid dan Mansyur, 2011:27).

Dengan demikian, berdasarkan pengamatan terhadap sistem pertahana di Maluku pada abad XVII-XIX dapa dikemukakan beberapa asumsi, diantaranya:

1. Berdasarkan keletakannya, bentengbenteng di Maluku ditempatkan di daerah pesisir/tepi pantai dan daerah perbukitan. Hal ini, berkaitan dengan strategi dan taktik perang maritim dengan melihat kondisi wilayah Maluku berupa kepulauan. Sementara benteng-benteng yang dibangun di daerah perbukitan merupakan kubu pertahanan terhadap perlawanan-perlawanan dari penguas lokal.

2. Daerah-daerah strategis di Maluku seperti Ternate, Ambon, Saparua dan Kepulauan Banda dibangun sistem pertahanan yang kuat. Ternate sebaga daerah penghasil cengkeh pada awalnya diperkuat oleh Portugis yang merupakan negara pertama yang mengeksplorasi daerah ini dan dilanjutkan oleh Belanda. Sedang Ambon dan sekitarnya diperkua karena merupakan pusat aktifitas Belanda di Maluku, daerah Saparua dan Haruku diperkuat karena adanya perlawanan yang kuat dari masyarakat dikedua daera tersebut. Sementara Kepulauan Banda 
merupakan penghasil pala terbesar di Maluku.

3. Perebutan pengaruh diantara negaranegara kolonial menjadi salah satu faktor (selain adanya perlawanan penguasapenguasa lokal) dibangunnya sistem pertahanan yang kuat di Maluku. Ternate menjadi ajang perebutan antara Portugis dan Spanyol, sementara Kepulauan Banda dan Spanyol, sementara Kepulauan Banda
diperebutkan oleh Belanda dan Inggris. Demikian halnya dengan Ambon menjad rebutan diantara negara-negara kolonial, namun berhasil dikuasai oleh Belanda dengan menduduki benteng pertahanan yang kuat, peristiwa ini diabadikan dengan memberi nama benteng tersebut Nieuw Victoria (Mansyur, 2006).

\section{Tata Niaga Cengkeh dan Pala}

Sebelum kedatangan bangsa Eropa perdagangan rempah-rempah di Maluku didominasi oleh pedagang-pedagang Cina, Arab, dan pedagang pribumi. Namun, sejak kedatangan bangsa Eropa perdagangan rempah-rempah menjadi rebutan diantara par pedagang Eropa. Dimulai dengan kedatangan bangsa Portugis pada tahun 1512, kemudian oleh Belanda pada tahun 1599. Persaingan diantara kedua pedagang Eropa tersebut berakhir dengan kemenangan Belanda yang berhasil mengusir Portugis dari Maluku pada tahun 1605. Belanda melalui perusahaan dagangnya yaitu VOC, kemudian menjadikan Ambon sebagai pusat pemerintahan selama tiga masa jabatan Gubernur Jenderal yaitu sejak tahun 1610 hingga tahun 1619 (Ricklefs, 2008; Mansyur, 2011).

Keberhasilan Belanda mengusir Portugis, menyebabkan Belanda semaki leluasa menerapkan sistem monopoli rempahrempah di Maluku. Untuk memantapkan sistem ini, Belanda berusaha meredam berbagai perlawanan lokal di beberapa daerah diantaranya; Hitu (P. Ambon) pada tahun 1634 (Rijoly, 1989), Iha (P. Saparua) pada tahun 1632 (Hitipieuw, 1984), dan Banda (Kep. Banda) pada tahun 1620-an (Ricklefs, 2008; Mansyur, 2011).
Berdasarkan data sebaran benteng yang ada menunjukkan hingga pertengahan abad ke-17, Belanda telah berhasil membangun benteng di tiap pulau yang ada di Maluku (khususnya Pulau Ambon dan Kepulauan Lease serta Kepulauan Banda). Dukungan sistem pertahanan ini semakin memantapkan pula kebijakan untuk memusatkan komoditi rempah-rempah di kedua wilayah, yaitu; dan Kepulauan Lease, sert Kepulauan Banda. Hal ini ditandai dengan keberhasilan Gubernur de Vlaming pada Januari 1652, untuk mendesak Sultan Ternate Mandar Syah menandatangani perjanjian tentang pelarangan penanaman pohon cengkeh di wilayah Maluku (dan Maluku Utara) kecuali di Pulau Ambon dan pul pulau kecil di sekitarnya. Kebijakan ini diikuti pula dengan pemusatan penanaman pohon pala di Kepulauan Banda. Tidak hanya fungsi pertahanan, fasilitas berupa gudang komodit serta dermaga yang melengkapi fungsi perdagangan, menjadikan benteng sebagai pendukung utama tata niaga rempah-rempah di Maluku (Mansyur, 2011).

Selanjutnya, untuk menjamin pelaksanaan perjanjian ini, Belanda menerapkan kebijakan lain yaitu pelayaran hongi atau ekspedisi hongitochten. Pelayaran hongi atau armada hongi adalah pengerahan armada kapal yang dipersenjatai untuk melakukan pengawasan terhadap daerahdaerah penghasil cengkeh. Pelayaran hongi telah berlangsung sejak masa pendudukan Portugis dan sistem ini dilanjutkan oleh Belanda setelah berhasil merebut penguasaan atas wilayah ini. Sejak pemerintahan Portugis, telah berlangsung hubungan antara penduduk Leitimor (bagion timur Pulau Ambon) untuk menyediakan perahu pengangkut yang menyediakan perahu pengangkut yang
disebut dengan kora-kora (perahu tradisional disebut dengan kora-kora (perahu tradisional
Maluku). Armada inilah yang kemudian digunakan untuk melaksanakan pelayaran hongi atau pada masa Belanda disebut ekspedisi hongitochten (Pattykayhatu, 2009).

$$
\text { Kebijakan lain yang mendukung }
$$

sistem tata niaga rempah-rempah, khususnya cengkeh adalah keberhasilan Belanda mencampuri struktur sosial penduduk pribumi. Di Maluku khususnya di pulau Ambon dan kepulauan Lease, sistem desa dinamakan Negeri. Struktur masyarakat yang dinamakan negeri tersebut sebetulnya baru timbul pada abad ke- 17 ketika VOC mencampuri kehidupan penduduk dengan maksud mengamankan sistem monopolinya. Dalam struktur sosial tersebut, pengaturan tentang tata niaga cengkeh tampak pada tugas dan kewajiban kepala desa (raja) yang telah ditentukan oleh Gubernur yaitu mengawasi penanaman, pemeliharaan dan panen cengkeh. Selain itu, Raja mendapat jatah "kwarto" atau orang-orang yang dapat dipekerjakan mengolah kebun, mencari ikan, memperbaiki rumah maupun pekerjan lain yang bersifat pribadi (Pattykayhatu, 2009 dalam Mansyur, 2011)

Sementara itu, Berdasarkan peta yang dibuat oleh Van de Wall pada tahun 1928, memberikan informasi bahwa secara keseluruhan terdapat 33 perken di Kepulauan banda, dengan rincian: 3 perken di Pulau Banda, 6 perken di Pulau Ay, dan 24 perken di Pulau Lonthor. Belanda kemudian menerapkan sistem yang berbeda untuk komoditi pala dengan adanya perken atau perkebunan pala. Sistem ini dilakukan dengan membagi tanah-tanah subur di tiap pulau yang ada di Kepulauan Banda, yaitu Pulau Ay, Pulau Lonthor, dan Pulau Banda. Pembagian ini mulai dilakukan sejak tahun 1616, dan selesai pada tahun 1628. Perkebunan pala ini kemudian diserahkan kepada orang-orang Eropa yang memiliki modal dengan sistem sewa. Namun, seiring dengan perjalanannya, perkebunan-perkebunan yang telah dibagi tersebut berubah menjadi hak milik, dan mengalami banyak perubahan, baik perluasan areal dengan cara membeli maupun pengurangan areal dengan adanya pembagian dalam bentuk warisan kepada generasi selanjutnya (Rijoly, 1989). Perkebunanperkebunan ini kemudian diolah dengan mendatangkan pekerja-pekerja dari Jawa, Buton, dan daerah-daerah lain, hal ini karena keberhasilan Belanda menguasai daerah ini (Mansyur, 2011).

\section{Perkembangan Morfologi Kota}

Daerah-daerah yang dianggap penting oleh Belanda pada masa pendudukannya di wilayah Maluku, diantaranya; Ambon, Saparua, Banda, Namlea, Ternate, Tidore, dan Bacan. Berdasarkan hasil penelitian, diperoleh gambaran tentang awal pembentukan kota, yaitu Saparua, Namlea, dan Bacan. Secara umum, embrio sebuah kota diawali dengan pendirian sebuah benteng, dimana fungsi benteng tidak hanya pertahanan tetap juga pusat pemerintahan, ekonomi, dan sekaligus sebagai pemukiman. Kota kemudian berkembang dengan membangun berbagai fasilitas tidak jauh dari dinding benteng. Umumnnya, fasilitas utama yang dibangun adalah kantor serta rumah tinggal perwakilan pemerintahan. Kota kemudian dilengkap dengan berbagai fasilitas lain yang dapat mendukung aktivitas warga kota, misalnya sekolah, rumah sakit, pasar, dan dermaga. Elemen lain yang membentuk kota adalah toponim-toponim yang merupakan daerah pemukiman yang dipisahkan berdasarkan etnis.

\section{EVALUASI HASIL PENELITIAN}

Aspek-aspek yang dapat dijadikan titik tolak evaluasi dalam kajian pengaruh kolonial, yaitu: permukiman-perkotaan pelabuhan-jaringan perdagangan, teknologi industri dan irigasi, arsitektur rancang bangun, institusi sistem pemerintahan, lingkungan, religi, dan bidang pengembangan (Harkatiningsih, 2009)

Berdasarkan ruang lingkup hasil penelitian yang telah dipaparkan sebelumnya maka hasil penelitian telah memberi informas tentang cakupan aspek permukimanperkotaan, pelabuhan-jaringan perdagangan, dan institusi sistem pemerintahan. Meski demikian, masih dibutuhkan pendalaman kajian khususnya tentang pertumbuhan dan perkembangan kota secara sinkronis. Pada aspek pelabuhan-jaringan perdagangan dapat dijelaskan tentang jaringan loka komoditi khusus rempah-rempah, dan kajian yang masih perlu didalami adalah 
daerah-daerah penghasil komoditi lain. Aspek institusi sistem pemerintahan dapat dijelaskan tentang keterlibatan pihak asing dalam mengatur penguasa lokal untuk kepentingan mereka khususnya yang terkait dengan kepentingan ekonomi dan politik. Titik perhatian yang dapat menjelaskan aspek ini adalah pentingnya penulusuran data sejarah. Selain itu, bukti material berupa bangunan perbentengan yang memperlihatkan sistem pertahanan, dimana benteng memilik berbagai fungsi termasuk pusat pemerintahan dan perdagangan.

Sementara itu, aspek lain yang masih harus dikaji diantaranya berkaitan dengan arsitektur rancang bangun, lingkungan, religi, dan bidang pengembangan.

1. Arsitektur rancang bangun, karakte arsitektur ditandai dengan beberapa cir yang menunjukkan fase pembuatannya, sehingga dibutuhkan kajian untuk mengenali ciri-ciri tersebut untuk mengetahui masa pembuatan atau kronologinya. Tidak hanya itu, penting juga untuk melihat apakah terdapat unsur arsitektur tradisional pada bangunan kolonial atau sebaliknya. Tema ini terutama sangat terbuka untuk dikaji pada bangunan kolonial seperti yang di Kota Banda.

2. Lingkungan, aspek ini untuk melihat penerapan adapatasi lingkungan, mis: pengaruh lingkungan terhadap keletakan suatu bangunan, kajian ini juga untuk melihat keterkaitan antara kondisi lingkungan dengan sumberdaya alam.

3. Religi, aspek ini berkaitan dengan proses penyebaran agama yang dibawa oleh bangsa Eropa pada daerah-daerah kekuasaan mereka. Tidak hanya itu, penting untuk mengetahui pengaruh relig terhadap budaya masyarakat setempat, mis: adanya sasi gereja. Selain itu, kita mengenal adanya pembagian ruang (penempatan) perangkat negeri dalam setiap ibadah yang dilaksanakan di gereja.
4. Bidang pengembangan, diantaranya melalui kegiatan diskusi, pameran maupun dalam bentuk lomba karya tulis ilmiah yang secara berkala dilaksanakan ilmiah yang secara berkala dilaksanakan
setiap tahun. Meski demikian, kegiatankegiatan ini tidak menyentuh secara khusus tema pengaruh kolonial. Selain kegiatan-kegiatan tersebut, juga perlu membangun forum komunikasi lintas sektoral terkait dengan penelitian dan pengembangan (pelestarian, pemanfaatan, pengelolaan, informasi, dan CRM) Peranan dalam bidang pengembangan dapat pula dilakukan dengan mendorong terbentuknya museum sebagai media pendidikan bagi masyarakat terkai dengan tema pengaruh kolonial, mis: museum kota Ambon, museum benteng museum negeri, dll. Dalam lingkup internal, hal penting dan mendasar untuk segera dilakukan adalah membangun database hasil-hasil penelitian, karena saat ini bank data telah siap diolah agar data yang ada saling terintegrasi dan mudah untuk diakses.

\section{PENUTUP}

Hasil penelitian yang telah dilakukan oleh Balai Arkeologi Ambon, secara khusus pada tema pengaruh kolonial telah memberikan sumbangan informasi yang dapat mengungkap berbagai hal tentang masa penguasaan kolonial di nusantara Sumbangan informasi ini khususnya terkai dengan jaringan lokal perdagangan rempahrempah di Kepulauan Maluku. Output hasil penelitian setidaknya dapat digunakan sebagai salah satu bahan dalam rangka perencanaan pembangunan daerah, seperti revitalisas tinggalan arkeologi masa kolonial. Selain itu, juga dapat digunakan sebagai wahana wisata maupun pemanfartan (dengan tetap pada semangat pelestarian) yang lebih luas dan aktual.

Terkait dengan berbagai aspek yang belum dapat dijelaskan, tentunya menjadi bahan untuk pelaksanaan penelitian selanjutnya. Diakui pula bahwa banyak kelemahan dalam pelaksanaan penelitian yang masih perlu dibenahi termasuk menata ulang perencanaan penelitian yang lebih strategis agar kualitasnya dapat terus ditingkatkan.

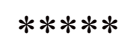

\section{DAFTAR PUSTAKA}

Abbas, 2005, "Sistem Pertahanan di Batavia Abad CVII-XVIII", Dalam Pertemua Ilmiah Arkeologi VII. Jakarta: Proyek Penelitian Arkeologi Jakarta. Proyek 1999.

Effendi, Ivan dan Mansyur, Syahruddin. 2007. Draft Awal Laporan Inventarisasi dan Identifikasi Benteng di Propinsi Maluku. Proyek Kerjasama Dirjen Sejarah dan Purbakala, Pusat Dokumentasi Arsitektur Indonesia, Passchier Architects \& Consultan Netherlands, dan Balai Arkeologi Ambon.

Hanna, W.A. 1983. Kepulauan Banda Kolonialisasi dan Akibatnya di Kepulauan Pala. Jakarta: PT. Gramedia.

Harkantiningsih, Naniek. 2009. Pengaruh Kolonial di Nusantara: Penelitian dan Pengembangan. Makalah dalam Evaluasi Hasil Penelitian Arkeologi (EHPA). Denpasar, 5-8 November 2009 : Pusat Penelitian da Pengembangan Arkeologi Nasional

Hitipeuw, Frans. 1984. Kerajaan Iha Berinteraksi dengan Segala Suku Bangsa di Abad XVII dalam Perjuangan Nasional. Jakarta: Departemen Pendidikan dan Kebudayaan, Direktorat Sejarah dan Nilai Tradisional, Proyek Inventarisas dan Dokumentasi Sejarah Nasional

Patikayhatu, dkk., 2009. Sejarah Negeri dan Desa di Kota Ambon. Ambon: Dinas Pariwisata, Kebudayaan, Pemuda dan Olahraga.

Pusat Dokumentasi Arsitektur. 2008. Field Survey Report Mid Year Evaluation: The Inventory and Identification of Fort in Indonesia. Disampaikan dalam Workshop Hasil Indentifikasi Benten di Indonesia Timur. Jakarta, 12 Juli 2008. 
Syahruddin Mansyur, Tinggalan Arkeologi Masa Kolonial di Wilayah Kepulauan Maluku: Sebuah Evaluasi .......

Ricklefs. M.C. 2008. Sejarah Indonesia Modern: 1200-2008. Jakarta: Serambi

Syahruddin, M. 2006. "Sistem Pertahanan di Maluku Abad XVII-XIX (Kajian atas Pola Sebaran Benteng)". Dalam Kapata Arkeologi Vol. 2 No. 3 November 2006 ISSN 1858-4101: 4763. Ambon: Balai Arkeologi Ambon.

.2011. “Jejak Tata Niaga Rempah-Rempah dalam Jaringan Perdagangan Masa Kolonial di Maluku". Dalam Kapata Arkeologi Vol. 7 No. 13, November 2011 ISSN 1858-4101: 20-39. Ambon: Balai Arkeologi Ambon. 